\title{
EDITORIAL
}

\section{Twenty years publishing science}

\section{Veinte años divulgando ciencia}

La Revista MVZ Córdoba es una publicación científica de la Facultad de Medicina Veterinaria y Zootecnia de la Universidad de Córdoba, Montería, Colombia. Su misión es la divulgación del conocimiento científico y tecnológico de las ciencias agropecuarias; y su visión es convertirse en referente de consultas en el ámbito nacional e internacional en el campo de las ciencias agropecuarias y promover valores éticos que contribuyan con el desarrollo de la investigación científica y tecnológica.

Este año se conmemora el vigésimo aniversario de la Revista MVZ Córdoba y, por lo tanto, es importante recordar algo de su historia.

El primer número de la revista fue publicado en 1994 con 11 artículos y este número constituyó el volumen uno. En la actualidad, la revista publica tres números por año que conforman un volumen con más de 75 artículos. En los veinte años de existencia de la revista, se han divulgado 579 artículos y el $62 \%$ de ellos correspondió a artículos originales. En este periodo han publicado 1856 autores, de los cuales el 35\% fueron locales; el $41 \%$, nacionales y el $24 \%$, internacionales.

Desde su creación, la revista ha desarrollado planes de mejoramiento relacionados con la calidad científica, calidad editorial, visibilidad, el arbitraje de artículos y la impresión. En los últimos siete años, por ejemplo, se divulgaron 368 artículos divulgados y el $73 \%$ de ellos correspondió a artículos originales. En este espacio de tiempo, participaron 412 autores internacionales y se emplearon 707 árbitros: $30 \%$ fueron internacionales; $60 \%$, nacionales y solo el $10 \%$, locales. También se ha incrementado la visibilidad, al indexar la Rev. MVZ Córdoba
The Journal MVZ Córdoba is a scientific publication of the Faculty of Veterinary Medicine and Zootechny of the University of Córdoba in Montería, Colombia. Its mission is to publish scientific and technological knowledge of agricultural sciences and its vision is to become a national and international consulting reference in the field of agricultural sciences and to promote ethic values that contribute to the development of scientific and technological investigation.

This year the Journal MVZ Córdoba celebrates its twentieth anniversary, which is an important time to remember something of its history.

The first issue of the journal was published in 1994 with 11 articles that made up volume one. Today, the journal annually publishes three issues that make up a volume of more than 75 articles. In the twenty years since the journal started, 579 articles have been published and $62 \%$ of them corresponded to original articles. During that time, 1,856 authors have published, of which 35\% were local; 41\%, national and 24\%, international.

Since its creation, the journal has developed improvement plans related to scientific quality, editorial quality, visibility, article refereeing and printing. In the last seven years, for example, 368 articles were published, and $73 \%$ of these were original articles. In this time, 412 international authors participated and 707 referees were used: $30 \%$ were international; $60 \%$ national and only $10 \%$ local. Visibility has also increased; the Journal MVZ Córdoba is listed in 32 new international databases 
en 32 nuevas bases de datos e índices internacionales y para este año, 2014, se actualizaron las instrucciones para los autores.

Además de historia, la revista tiene nuevos retos como, por ejemplo, realizar la publicación anticipada de la misma, ya que esta estrategia facilita la interacción oportuna entre investigadores y permite cumplir con los estándares nacionales e internacionales relacionados con esta materia.

Teniendo en cuenta lo anterior y que la generación y rápida divulgación del nuevo conocimiento son elementos fundamentales que contribuyen con el desarrollo y crecimiento de la sociedad; a partir de este año, 2014, la revista se empezará a publicar de forma anticipada y en dos idiomas: español e inglés.

En esta edición, queremos manifestar nuestro reconocimiento a todos los autores que creyeron en la Rev.MVZ Córdoba y enviaron sus artículos para sometimiento y publicación. A los árbitros que realizaron su valiosa e insustituible labor desde el anonimato, puesto que ellos revisaron y corrigieron, con independencia de criterio, los artículos que se les enviaron para ser evaluados. A todas las personas e instituciones que han formado parte de esta revista, desde su creación, impresión, publicación, dirección, capacitación, evaluación y financiación.

Asimismo queremos expresar nuestra gratitud a todas las autoridades académicas y administrativas de la Universidad de Córdoba que han apoyado esta iniciativa.

Para terminar, haciendo alusión a una estrofa de la canción "Volver" del famoso cantante argentino de tangos, Carlos Gardel, que reza... "Sentir, que es un soplo la vida, que veinte años no es nada, que febril la mirada errante en las sombras te busca y te nombra"... queremos expresar con lucidez que veinte años no es nada, pero que estamos listos para enfrentar los próximos veinte. and indexes, and this year, 2014, the instructions to authors were updated.

In addition to its history, the journal has future challenges. For example, there are plans to produce in advance publication which aids in timely interaction between investigators and allows for compliance with national and international standards related to the subject.

Keeping in mind the above and aware that the production and rapid dissemination of new knowledge are fundamental elements that contribute to the development and growth of society; starting in 2014, the journal will begin to have in advance publication in two languages: Spanish and English.

In this issue, we want to manifest our acknowledgment to all the authors that believed in the Journal MVZ Córdoba and submitted their articles for publication. Also to the referees that have performed a valuable and irreplaceable anonymous work, they guided the journal by independent criteria to check and correct articles submitted for evaluation. And also to all the people and institutions that have formed part of this journal in its creation, printing, publication, administration, training, evaluation and funding.

We also want to express our gratitude to the academic and administrative authorities of the Universidad de Córdoba that have supported this initiative.

Finally, we remember a line from the song "Volver" by the famous Argentine tango singer Carlos Gardel which says, "To feel that life is but a breath, that twenty years is nothing, how feverish the roving glance in the shadows that searches for you and speaks your name", we want to express that twenty years is nothing, and that we are ready to face the following twenty to come. 